\title{
Ficção-Verdade: Fronteira semiótica na montagem narrativa de Valêncio Xavier
}

\section{Reuben Rocha}

\section{Resumo:}

Este artigo propõe uma leitura da obra Rremembranças da menina de rua morta nua - montagem assinada pelo escritor Valêncio Xavier que recupera a história de um assassinato ocorrido em São Paulo na decada de 1990 - que a desloque do campo da literatura e a traga para a semiótica da comunicação. Amparando este desvio na hipótese de que a obra se situa entre o ficcional e o factual, o trabalho se serve do conceito de fronteira semiótica de Iúri Lotman para sugerir algumas chaves de leitura para o texto.

\section{Palavras Chave:}

Valêncio Xavier; Fronteira semiótica; Ficção; Montagem narrativa; Semiótica da comunicação

\begin{abstract}
:
This paper presents a reading of Rremembranças da menina de rua morta nua - a montage signed by Valêncio Xavier which recovers the story of a murder occurred in São Paulo during the 90's - which dislocates it from literature and analyzes it from the point of view of communication semiotics. Supported by the hypothesis that the text stands between fiction and fact, this paper uses Yuri Lotman's concept of semiotic boundary to suggest some reading keys to Xavier's text.
\end{abstract}

\section{Keywords:}

Valêncio Xavier; Semiotic boundary; Fiction; Literary montage; Communication semiotics

\section{Rremembrar, lembrar}

Aconteceu faz muito tempo mas eu ainda lembro bem (Valêncio Xavier, Coisas da noite escura)

No livro Rremembranças da menina de rua morta nua, o escritor e cineasta Valêncio Xavier (1933 2008) reconstitui a história de um assassinato ocorrido em 1993 - uma criança de rua é encontrada morta, nua, dentro de um caixão falso no trem-fantasma de um parque de diversões em Diadema, Grande São Paulo. A obra reconstrói o caso a partir dos relatos da imprensa policial da época, valendo-se ostensivamente de recortes de jornal, fotografias, locuções de reportagens televisivas e diversos outros fragmentos de linguagem factual. O desvio, o uso narrativo deslocado que lhes confere a montagem, sua riqueza ao mesmo tempo documental e imaginativa é que sugere a questão que inaugura este texto. De que modo ler as Rremembranças quando o sentido que produzem não é dissociável do estranhamento causado pelo fato que recuperam?

Neste deslocamento contido no próprio texto é que se apóia o gesto de pensá-lo como obra de fronteira entre o factual e o ficcional, que não se oferece integralmente nem como trabalho imaginativo nem como relato jornalístico. Os espaços de fronteira possuem a potência de gerar processos de significação imprevistos, fenômenos que exigem ferramentas de leitura diversas das oferecidas pelos campos entre os quais se situam. Daí que também se proponha um deslocamento na própria análise, ao se destacar o texto 
do campo da literatura para pensá-lo do ponto de vista da comunicação - esta velha conhecida da fronteira -, munido de ferramentas conceituais buscadas na semiótica da cultura de Iúri Lotman.

Não para encerrar, mas para acrescentar sentido a um texto polissêmico que, dá pra dizer, se existe é graças a um princípio polinizador de sentidos. Nem mesmo a busca do melhor lugar de análise, ou desconsiderar posicionamentos críticos já postos sobre a obra do autor, mas a ideia de que a um intrincado jogo de significações deve-se responder com igual indisciplina e heterodoxia. Mirar nesta outra possibilidade de leitura a emergência também possível de novas estruturas de recepção e sensibilidades diversas. Para não domesticar o texto, para aprender algo de seu movimento e, igualmente, mover-se.

A fronteira tal qual formulada pelo semioticista é um dispositivo aglutinador de linguagens, campo movediço em que do conflito entre gêneros surgem formações semióticas novas. Esta também a ideia que se pretende que contenha o título "Ficção-Verdade" - nomenclatura utilizada pelo próprio Xavier -, não como descrição suficientemente adequada ou mesmo como explicação, mas pura imagem que lembre o fato de que, ao se imiscuírem, os dois registros terminam por constituir um espaço semiótico autônomo, com chaves de leitura diferentes das que ambos oferecem autonomamente.

\section{Escrever com a tesoura}

Ele: o amalgâmico/ o filho das fusões/ o amante das algaravias/ o sem pureza (Waly Salomão, Domingo de Ramos)

Valêncio Xavier talvez mereça o título de escritor mais impuro da literatura brasileira. Sua obra recorre sistematicamente ao lixo esquecido da nossa cultura - palavras e grafias caídas em desuso, verbetes de dicionários etimológicos, imagens de filmes antigos e de cinemas que não existem mais, rótulos de balas e anúncios de produtos, recortes de jornal e histórias que caíram no esquecimento, todas destacadas de algum contexto já perdido e resgatadas para a memória literária. Narrativas deslocadas desde a origem: cada livro é na verdade a compilação de histórias publicadas esparsamente em jornais e revistas, às vezes décadas antes (1). Deslocadas desde o nome: no lugar de contos ou novelas, os arcaísmos "racontos" e "novellas". No lugar de lembrar, rremembrar. Detalhes em nada acessórios, elementos que não ilustram nada, por vezes constituem o núcleo central do trabalho criativo do autor - como se Valêncio escrevesse com uma tesoura, e não com uma caneta.

Lembre-se de $O \mathrm{Mez}$ da Grippe (1998), reconstituição da história da epidemia de gripe espanhola ocorrida em São Paulo, em 1918. Intrincada montagem que mistura a cobertura feita pela imprensa - contagem dos mortos, informações sanitárias, dados sobre o avanço ou retrocesso da epidemia - e anúncios publicitários da época - produtos para "desenvolver os seios", xaropes que servem para tudo, orações, anúncios de missas de sétimo dia - num arranjo em que os "grandes acontecimentos" não se sobrepõem aos detalhes da vida corriqueira e até caricata, elementos submetidos apenas à imaginação adúltera de Xavier, que embaralha a veracidade destes fragmentos de fatos com um discreto deslocamento: o autor adapta a epidemia paulista à Curitiba do começo do século, inscrevendo assim o documental no imaginativo. 


\section{DIA 19 TERGA}

\section{茫 \\ OS OBITOS DE HONTEM}

\section{NÃO HÁ AUMENTO NEM DIMINUIÇAOO}

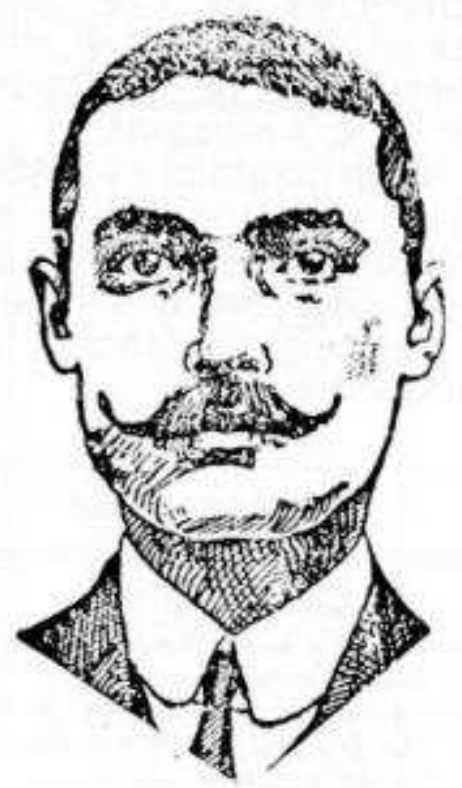

Ela geme baixinho, năo mais de febre agora de gòzo?

Gózo e no auge do gōzo tento abraçar todo seu corpo que se me escapa e tenho nas mãos como um pássaro peixe

Mas ainda há em $O \mathrm{Mez}$ da Grippe a voz reconhecível de um narrador nas brechas da memória, como em Crimes à Moda Antiga - Contos Verdade (2004), composto por histórias de assassinatos ocorridos no Brasil no início do século XX e coletadas pelo escritor nos porões da Biblioteca Pública e do Arquivo Oficial de São Paulo, e da Biblioteca Pública de Curitiba, as histórias são recontadas narrativamente, reconfiguradas em textos propriamente literários. Em outras obras a apropriação do factual e de materiais culturais pré-existentes é ainda mais radical, inserindo-os por vezes sem nenhuma intervenção no território 
da literatura.

Caso do texto recortado para este trabalho, Rremembranças da menina de rua morta nua, montagem realizada quase exclusivamente a partir de trechos de narrativas midiáticas e fragmentos perdidos de linguagem. Acrescentando comentários mínimos entre os recortes, Xavier constrói uma espécie de metanarrativa, ou narrativa em segundo grau, em que a voz do narrador surge apenas brevemente em meio ao núcleo composto pelo material colhido, produzindo um efeito de estranhamento decorrente não apenas da brutalidade do crime, mas da brutalidade das notícias, da brutalidade da memória do crime.

A brutalidade, no entanto, não é um tema novo na ficção ou no jornalismo. Na introdução a uma entrevista que realizou com Valêncio Xavier, o também escritor Joca Reiners Terron chama atenção para o fato de que mesmo a obra do autor "parece estar catalogando itens para a curadoria de um pequeno museu do crime, inscrevendo seu trabalho na tradição de violência, sexo e misoginia vinda desde Sade, passando por Baudelaire, Poe e Lautréamont, até desaguar no brutalismo visual e enigmático de Raymond Roussel e os surrealistas" (1999: 48-49). A violência, a crueldade, a perversão, são itens suficientemente recorrentes na literatura para que constituam uma tradição. O próprio uso de materiais não-literários se vincula a esta linhagem de autores, sobre a qual o crítico Claudio Willer observa que "contra o mito do gênio criador, defende a banalidade e elogia o chavão" (2008: 47). Nada mais próximo das páginas policiais compiladas por Valêncio. O que, então, justifica chamar sua obra de fronteiriça?

Esta tradição possui raízes na concepção romântica de combate ao realismo e ao naturalismo, "por não suportarem a realidade que os cercava e não admitirem que o mundo em que viviam lhes fosse dado como natural" (WILLER, 2008: 55). Nestes autores, os maiores arrebatamentos de crueldade são ataques plenamente imaginativos contra uma ordem social que elege o trabalho e a disciplina como princípios centrais de organização coletiva. E o uso de materiais "mundanos", extra-literários - que vão desde as prostitutas de Baudelaire até as narrativas visuais dos surrealistas, passando pelo plágio criativo de Lautréamont -, funciona como "subversão dos parâmetros do gosto" (p. 57). Tudo isso se explica do ponto de vista da literatura, a ponto de o crítico observar que restrições às perversões de um Marquês de Sade ou de um André Breton só poderiam decorrer de uma leitura literal de suas obras, que não contasse com "sua dimensão simbólica, alegórica ou metafórica", transformadora do impossível da existência em possibilidade de linguagem (p. 26).

É esta explicação que se acredita não dar conta da obra de Valêncio Xavier, é preciso considerar o deslocamento extremo de materiais realizado pelo escritor e o fato de tais materiais serem inscrições do factual na linguagem, somados a um título ou a uma assinatura, a uma frase ou outra, a uma moldura apenas, como os ready-mades de Marcel Duchamp, outro notório falsário, mestre na arte de descontextualizar/recontextualizar (2). A violência narrativa do autor é a que está posta nos cadernos policiais dos meios de comunicação. Amputados de seus contextos de origem, os crimes que chafurda dão testemunho da selvageria das histórias como do sensacionalismo dos jornais. Há um desconforto proporcionado por obras como Rremembranças da menina de rua morta nua que é o de se estar diante de um trabalho imaginativo em cuja crueza reside um retrato da brutalidade com que a própria sociedade se representa.

Se os excessos brutalistas de Lautréamont ou Baudelaire se exibem como diamantes da imaginação literária ou reações à ordem burguesa, não lhes cabendo uma leitura literal, não parece interessante excluir certa tensão de literalidade da leitura da obra de Valêncio Xavier. Não se trata, evidentemente, de diminuir sua grandeza imaginativa ou de relativizar seu trabalho artístico mediante qualquer reprovação de "sensacionalismo" - hipótese que, não custa lembrar, anularia por princípio este texto. Trata-se antes de chamar atenção para os deslocamentos possibilitados por esse mesmo trabalho refinadíssimo de criatividade. O lixo - o sensacionalismo, a crueldade - é nosso. Valêncio o recicla com um refinamento 
vindo em grande medida desta duplicação limiar - o fato e seu relato, a brutalidade e sua representação.

\section{Habitar a fronteira}

Só misturando pra ver no que vai dar (O Rappa, O Homem Amarelo)

A noção de fronteira em que se ampara esta proposta de leitura deriva do trabalho teórico e descritivo de Iúri Lotman (1996) acerca daquilo que chamou semiosfera - espaço em que se processam os fenômenos semióticos e fora do qual não há significação possível. Fronteira que a demarca ao estabelecer o outro semiótico, aquilo que está fora dos limites de uma semiosfera quer por pertencer a outro espaço semiótico quer por tratar-se de espaço não-semiotizado. O conceito interessa aqui na medida em que excede a ideia de linha divisória para comportar também o território que pertence simultaneamente aos espaços que separa, pondo-os em contato, traduzindo textos de um a outro e constituindo um espaço autônomo, fundado na intersecção.

Sob tal perspectiva a fronteira se caracteriza por fluidez e intensidade dos processos de significação. Comparativamente aos centros semióticos, locais normatizados e estabilizados por gramáticas culturais, a fronteira é sede de eventos imprevisíveis, possibilitados por trocas - entre gêneros, linguagens, línguas imprevistas. É local privilegiado de novidade de formações, já que

a não homogeneidade estrutural do espaço semiótico forma reservas de processos dinâmicos e é um dos mecanismos de produção de nova informação dentro da esfera. Nos setores periféricos, organizados de maneira menos rígida e possuidores de construções flexíveis, "deslizantes", os processos dinâmicos encontram menos resistência e, por conseguinte, se desenvolvem mais rapidamente. (LOTMAN, 1996: 30. Minha tradução (3).)

Há nisto um "impetuoso auge semiótico-cultural", que leva a periferia a transformar a natureza do centro e mesmo a ocupá-lo, passando a exercer sua função. Ora, se a fronteira é território de ebulição e novidade informacional, e operando o centro segundo categorias culturais reconhecíveis, é natural que o movimento das bordas até o centro seja um movimento de estabilização.

Mais do que isso, ou antes disso: por conta desse movimento o autor anota ser mesmo possível que uma formação semiótica inovadora seja nomeada com os termos reconhecíveis do centro, que ainda entenda a si mesma por meta-categorias de estruturas antigas (p. 30). Vinho novo em vasos velhos, formações inovadoras seladas com nomes que não lhes dão mais conta, pacificadas. A observação é útil para elucidar a jogada de minha empreitada - mais do que ler textos de fronteira, uma vez que os lugares da cultura não são estáticos, ler os textos enquanto habitarem a fronteira, enquanto não puderem ter um nome. $\mathrm{O}$ que talvez possa ser dito simplesmente: lê-los enquanto durarem no movimento.

Em The notion of boundary (1999) há uma ênfase da parte de Lotman em destacar a matéria de que a fronteira é feita. Neste campo de tensão em que espaços semióticos entram em choque e se misturam ao se tocarem, precipitam-se novas formações ao mesclarem-se gêneros, que passam a ser preservados na estrutura da linguagem resultante como memória (p. 138) - conceito em torno do qual se organizam mecanismos-síntese da própria concepção lotmaniana de cultura.

Há para o semioticista duas operações que condensam o funcionamento da cultura - uma primeira de conservação e transmissão, e uma segunda de elaboração de textos. São indissociáveis: textos novos 
surgem do uso que se faz do material conservado na memória da cultura. Este o significado de uma memória criadora - como Lotman nomeia o modo de lembrar típico da literatura e das artes -, o de servir à criação. Longe de ser um baú de guardados, "a memória não armazena textos, ela os produz" (1996: 158), de modo que a permanência de um texto na memória cultural significa ao mesmo tempo a manutenção de seu sentido e sua transformação.

E o contrário: a composição de um novo texto responde a textos anteriores, necessariamente produto e produtor de outros, elo na cadeia geral dos significados da cultura, que estabelece vínculos do passado para o presente e do presente para o passado. É neste sentido que Lotman afirma que presente e passado lêem um ao outro, o passado constituindo uma chave de leitura para o presente, e o presente acrescentando camadas de significação ao passado. Dinâmica contida em cada gesto de leitura e que lhe dota, à leitura, de certa envergadura criativa tanto quanto desmistifica na escrita certo individualismo criador, não importando o grau de consciência que tenha disso o autor ou o leitor.

Isso tudo emerge de maneira muito palpável na obra de Valêncio Xavier. Pensando em Rremembranças, a história da menina morta permanece como fato enquanto o próprio gesto de resgatá-la contém um movimento criador. A memória das formas jornalísticas se preserva, mas sua reutilização estabelece outro lugar de leitura e lhe acrescenta sentido: lemos a informação do crime, mas, num outro nível, não a lemos mais como notícia. Há a memória do fato e a da própria linguagem, da qual é possível se aproximar com curiosidade semelhante à com que se vai ao museu - postando-se diante de coisas reconhecíveis, mas que já estão aquém do seu uso original e além do seu significado primeiro.

\section{Montagem como ferramenta da memória}

Método de trabalho: montagem literária. Não tenho nada a dizer. Somente a mostrar. Não surrupiarei coisas valiosas, nem me apropriarei de formulações espirituosas. Porém, os farrapos, os resíduos: não quero inventariá-los, e sim fazer-lhes justiça da única maneira possível: utilizando-os.

(Walter Benjamin, Passagens)

A visibilidade disso que se descreve no trabalho de Valêncio Xavier reside na recorrência do recurso da montagem - procedimento que equivale aqui ao uso desviado, propositadamente descontextualizado, de materiais pré-existentes. Desvio que é "o contrário da citação, da autoridade teórica (...); fragmento arrancado do seu contexto, do seu movimento, da sua época como referência global" (DEBORD, 1997: 134). Blocos de citações empilhados sem a mediação de aspas ou interpretações. O passado é deslocado para o presente, e isso basta para transformá-lo noutro texto, para que irradie novos sentidos (4). Fragmentos de linguagem - jornalística, televisiva, fotográfica - que se esbarram e aí já são outra coisa, diferente do jornal, do telejornal ou da fotografia. Diferente da literatura. Algo que seria precipitado nomear, mas que foi possível de escrever. E é possível descrever.

O que conduz a história da menina morta (cujo nome é permanentemente preservado pela tarja preta) são falas e entrevistas retiradas do Aqui Agora, extinto programa de jornalismo policial do SBT (1991-1997), ele próprio o contexto da narrativa. Cena um: recorte de matéria do Jornal do Brasil. "Surgido como versão visual das apelativas crônicas policiais radiofônicas, o telejornal Aqui Agora (...) não defende mais as cores explícitas da violência." (XAVIER, 2006: 40). Corta. Deslocamento um: na página seguinte, a primeira reportagem feita pelo Aqui Agora> sobre o assassinato. A descrição do cenário (um terreno baldio), a reprodução da fala do repórter Gil Gomes, tudo contradiz com estridência o texto do JB, que data de 27 de março de 1993, enquanto a reportagem do programa é do dia 08 de abril do mesmo ano. 


\title{
0 programa mais 'cult' da elii
}

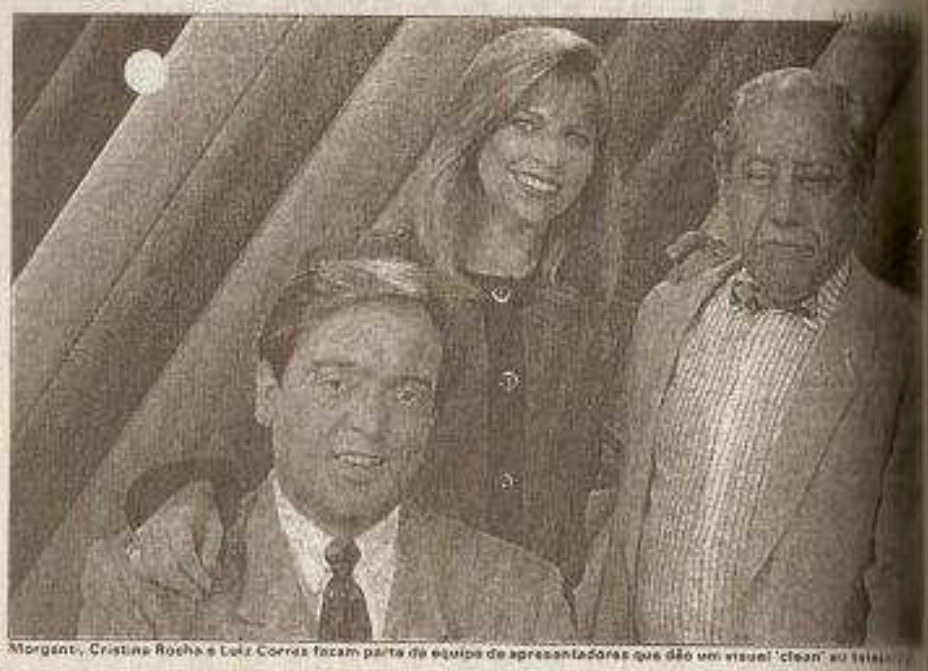

\author{
AQUIAGORA \\ A UITIMA VLAGEM DA PEQUENA
}
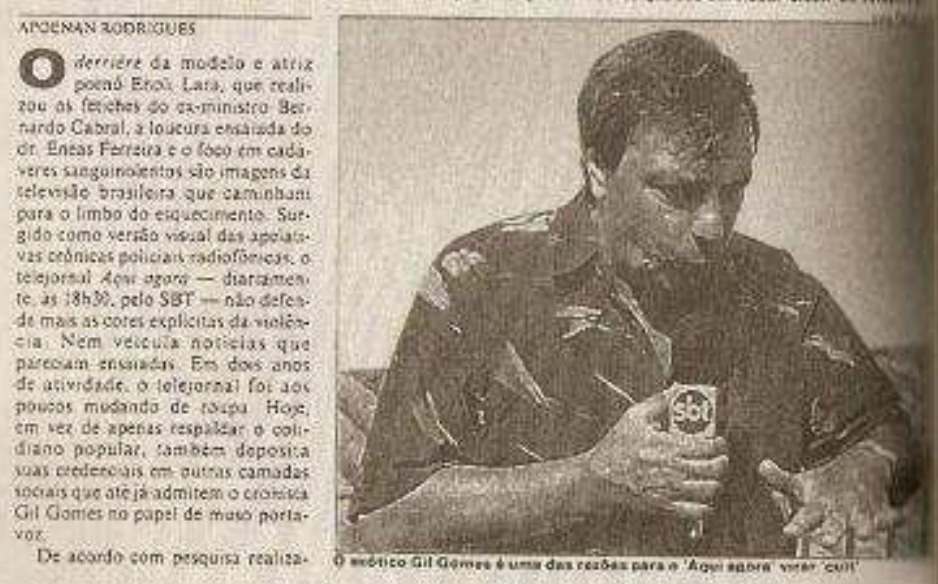

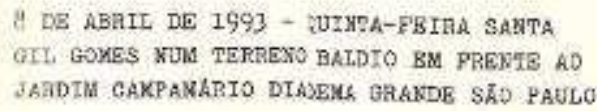

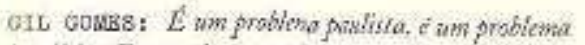

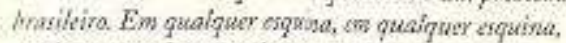

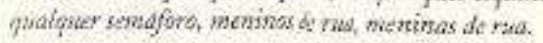

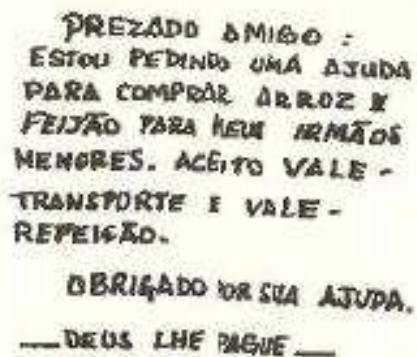

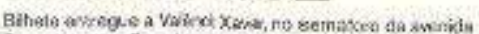
Sapeluso com Francisco brato ne quirts ferra 15i $4.93-8$

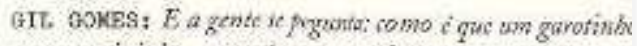
umas meriminba, come ze que wma crianca re transforma en monino de rua? Como i gue ama neninisha se transforne el menina de riat...

A crítica, num sentido tradicional, é substituída pelo confronto direto de materiais. A montagem não acusa a reportagem de sensacionalista, apresenta-a. Problematiza a veracidade da matéria do JB exibindo cruamente as datas, sem mediação alguma, e ao mesmo tempo ela segue funcionando como contexto, descrição de cenário: estamos em 1993, certo canal de televisão exibe uma "versão visual das apelativas crônicas policiais radiofônicas", que anuncia uma não-cumprida mudança de roupagem e noticia o assassinato brutal de uma criança de rua.

Como serve de contexto a inserção feita entre os dois parágrafos iniciais de Gil Gomes. "É um problema paulista, é um problema brasileiro. Em qualquer esquina, em qualquer esquina, qualquer semáforo, meninos de rua, meninas de rua", o repórter inicia o ritual. Corta. Reprodução dum bilhete em que se pede ajuda "para comprar arroz e feijão para meus irmãos menores", entregue a Valêncio Xavier "no semáforo 
da avenida Sepetuba com Francisco Morato na quinta-feira 15/04/93 - SP”, conforme a legenda (XAVIER, 2006: 41). Registros distintos de linguagem (trechos de reportagem televisiva/cartões escritos por crianças de rua) operando num terceiro registro (obra literária) como camadas descritivas.

Valêncio mesmo, na já mencionada entrevista concedida a Joca Reiners Terron, chama atenção para este método. Comentando uma cena de seu $O \mathrm{Mez}$ da Grippe, o escritor compara:

No Mez da Grippe, tem uma cena de um alemão que cria um incidente no Teatro Hauer. Como Balzac escreveria essa cena? Descreveria o personagem, detalharia o teatro e então contaria o que aconteceu lá dentro. Eu fiz a mesma coisa, só que coloquei um desenho tirado de um anúncio da época, de um sujeito que me pareceu capaz de realizar aquela ação, daí coloquei uma foto do Teatro Hauer e então reproduzi uma notícia de jornal que descrevia o incidente. Fiz a mesma coisa que Balzac faria, só que , em vez de palavras, usei imagens e imagens de palavras. (XAVIER, 1999: 51. Grifo meu.)

Nas Rremembranças o escritor funde sob a saia transparente da montagem a intenção descritiva própria da literatura com as "imagens e imagens de palavras" do ocorrido e seu contexto, substituindo radicalmente a descrição pela apresentação.

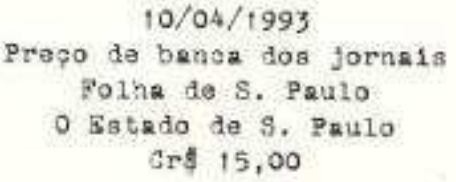

\section{MORTE NO TREM-FANTASMA}

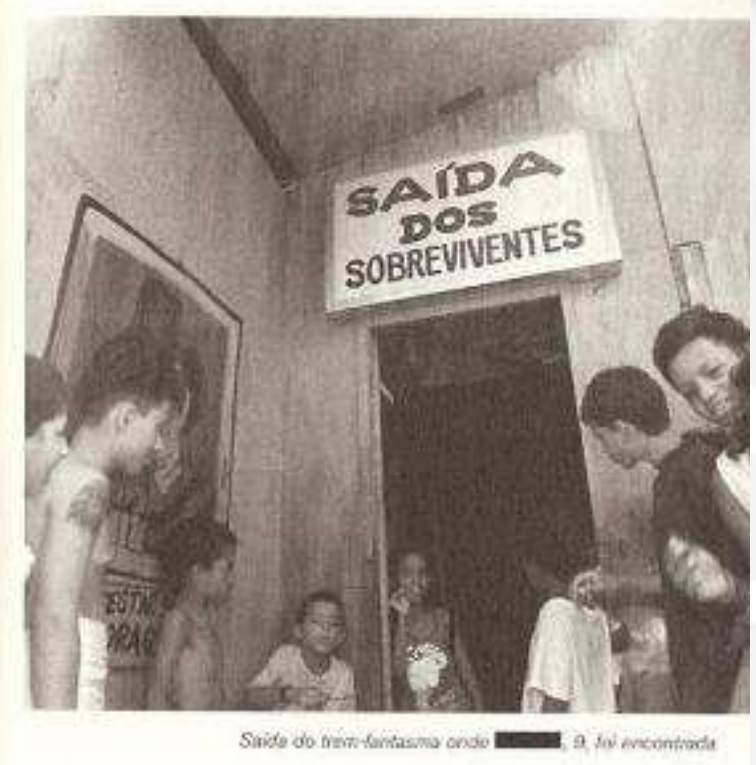

O gerente disse em depoiments à policia que realmente deu di. nheiro para comprar päo e cigarro. Segundo ele. depois da compra ele nảo viu a menina.

ค\%.

a convidou para tumar crack e manter relacỏes sexuais. ces- sets

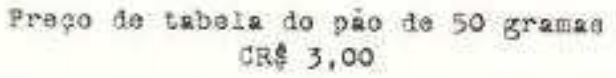

\section{Prefeitura interdita parque de diversões}


Entretecidos com as locuções de Gil Gomes, outros fragmentos de informação, recortes de jornal (Folha de S. Paulo e Estado de S. Paulo), fotografias, depoimentos de suspeitos e conhecidos da vítima. É assim que somos atirados no ano de 1993. Acompanhamos o intervalo comercial do Aqui Agora, vinhetas de outros programas, somos informados sobre a previsão do tempo, reajustes na caderneta de poupança, o preço de tabela do pão e dos jornais diários, e estas coisas falam menos de si do que de certa configuração social.

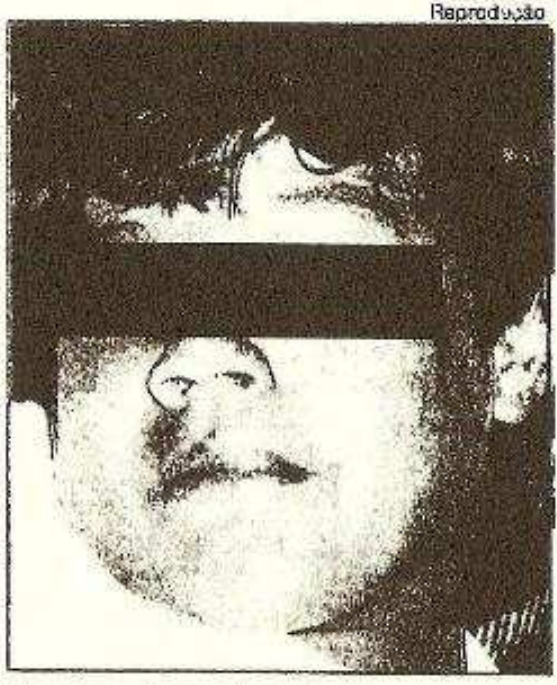

\section{Empregado a teria convidado para manter relação sexual}

GIL GOMES: A bistória dessa menina que você vê agora, seu nome sua idade nove anos de vida. uma menina de rua. Por quêt? Por quêt?

\footnotetext{
Lembrar, v. Do lat, memoraro, <lembrar, contar, mencionar; fazer mençāo de, falar a respeito de; lembrar que>. Houve as fases intermediárias: membrar e nembrar 1. Da primeira que parece ter-se arcaizado cedo só conheço esta abonaçäo do séc. xli: $<c$, pero era menyno, | rrosismibra-me que foi assi> Afonso X o Sábio, Cantigas de Santa Maria, No 256, em J. J. Nunes. Crestonacia Arcaica, p. $423,2^{2}$ ed. Nembrar na mesma epoca: $<$ Des que a non vi, no er vi pesar / $D$ al, ca nunca mi d al pudi nembrary, D. Dinis, no C. B. N., Nv [468] Dicionário Etymológico da Lingua Portuguesa de José Pedro Machado
}

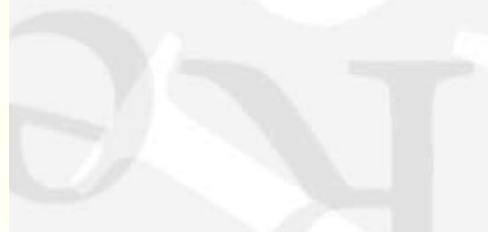


De recortes de verbetes de dicionário surgem mais camadas narrativas, a explicação de rremembrar, por exemplo, forma arcaica do verbo lembrar - o passado lido por linguagem passada. Eles motivam conexões por vezes surpreendentes, como no caso da palavra nênia ("canto fúnebre"), evocada no texto por conta de sua semelhança ortográfica com Nena, apelido de um dos suspeitos do crime. Associações que precipitam significados novos a partir de realidades textuais prévias, transformando detalhes e acasos num continuum de sentido.

E mergulhamos nos desníveis narrativos, nos entretextos, nos relevos de solda da montagem, para enxergarmos o sentido em que Rremembranças é uma obra original e ao mesmo tempo um mosaico documental, uma trama de vozes alheias e um texto autoral, composto na fronteira entre uma história grotesca e a criação deslumbrante. Ao lermos o relato sobre a menina morta, lemos de que maneira nos contamos sua história no já distante ano de 1993. A linguagem policial revela mais do que o caso de polícia que registra. Vemos o retrato de uma época na fotografia de sua linguagem.

\section{Ficção-Verdade}

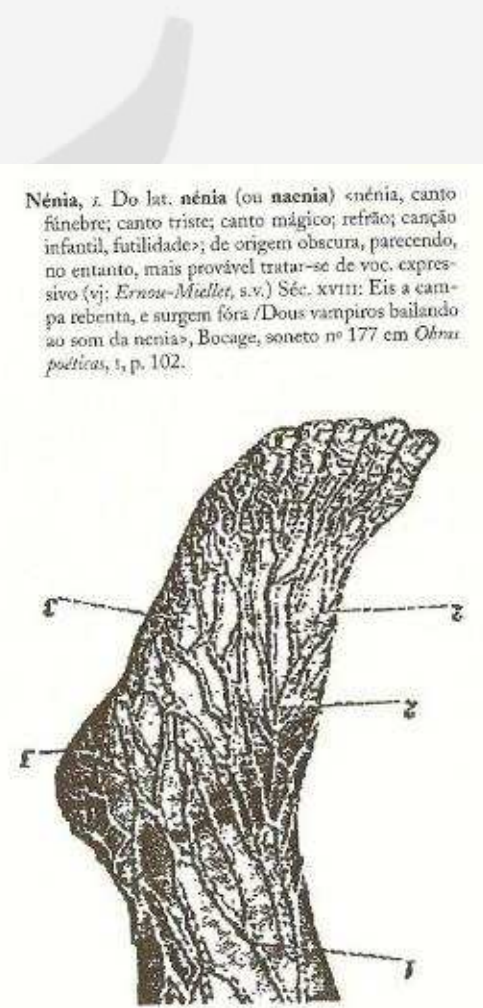

"Quando nós abrimos um dos caixōes, apareceu um pé da garota morta e saímos correndo para avisar os donos do parque", contaram os dois na polícia. O corpo de estavia em decomposição, e próximo ao caixão foram encontradas as suas roupas. Ela tinha um grande ferimento na cabeça.

GG: Num caixão que era para dar susto de brincadeira ali estava a menina. Ali estava
Do Letes/ brotam letras como lixo (Maiakovski, A Plenos Pulmões)

É curioso que, embora o universo policial seja um velho conhecido da imprensa e do rádio no Brasil, o telejornal sensacionalista, a não ser por experiências esparsas, surja de maneira sólida apenas na década de 1990. No artigo $D a$ pancadaria explícita à violência invisível, o professor Eugênio Bucci demarca um momento de passagem no qual a televisão

não tinha escolha. No negócio do entretenimento, ao menos no Brasil, a espetacularização do mundo-cão deixou de ser um item opcional para ser obrigatório. Assim, o tabu do mundo-cão dentro do vídeo - que já havia sido subvertido em tentativas isoladas - foi quebrado no final da década de 80. (1993: 102)

O gênero aos poucos ganha espaço na TV brasileira, até atingir seu mais alto grau de popularidade em 1991, justamente com a estreia do Aqui Agora.

Pródigo em misturar reportagens sanguinolentas, humor e prestação de serviços ao consumidor, para o bem e para o mal e por diversas razões o programa pode ser definido como "um gueto de autenticidade. Feia, grosseira, periférica, ignara autenticidade". A espetacularização da violência está na raiz do Aqui Agora, e Gil Gomes "leva ao vídeo a face mais bárbara da barbárie (...). A maior densidade do que se convencionou chamar de violência em televisão sai da [sua] boca e habita os lugares que ele visita com sua câmera" (BUCCI, 1993: 105-107), olho mecânico 
de imagem tremida, primitiva e pouco editada, sobreposta à locução gritada e redundante do repórter.

O universo policial é também um velho conhecido de Valêncio Xavier. Em sua longa carreira na televisão - foi produtor de Silvio Santos e fez roteiros para o humorista Ary Fontoura, para ficar com poucos exemplos -, o escritor foi uma espécie de pioneiro do gênero que adquiriu fama com o Aqui Agora. Na entrevista a Joca Reiners Terron ele lembra que em uma curta temporada em São Paulo, na década de 1960 ,

(...) fui pra Globo, onde fiz como o Túlio de Lemos (já falecido) o Processo 68. Era um programa que misturava ficção e documentário rememorando crimes insolúveis, com a assessoria da Secretaria de Segurança Pública. Eu recebia aqueles inquéritos policiais cheios de fotos dos assassinados, degolados, mulheres estupradas e mortas, envelopes com balas manchadas de sangue, coisas assim. Eu chegava em casa de noite, ficava com medo de entrar e ver as paredes cheias de sangue e minha mulher estirada, morta. Não sei se esses inquéritos influenciaram minha maneira de escrever. (XAVIER, 1999: 50)

\section{AQUI E AGORA}

\section{GIL GOMES ENTREVISTA A MÃE DE}

Você tinha doze anos. Doze anos? Doze anos. Vocé arrumou o Toninbo como namorado. Como namorado. Parecia aquela paixão de menina, ele parecia o Principe Encantado. Príncipe Encantado. (Gil olha para a câmera) E ela se entregou a ele. (Ela concorda com a cabeça) Uma vizinha viu e contou para sua mäe. Contou para minha mãe e aí meu pai ficou desesperado que ele falava sempre quando eu me perdesse ele ia me dar sete facadas meu pai falava. Aí me levou até a Polícia pra fazer exame delito. Te colocou para fora de casa. Colocou fora de casa me deixou na rua. Ai uma sucessäo de problemas. Altos probremas. (Chora) Minha vida é uma novela. Eu vô contá tudo. Nem um livro maior que o mundo enche ele. (Gil Gomes olha firme para a camera) Cada homem que se aproximava dela a queria somente para a cama e assim ela foi vivendo. $E$ assim o tempo foi passando. Um filho, dois. Quantos filbos? Dez? Sete? Sete filhos. Tenho sete filhos fora o que já morreu.

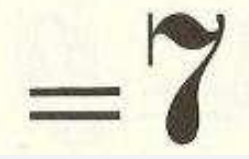


Nem é o caso de descobrir, a influência não é uma questão no âmbito deste texto. Mas cabe um paralelo. Este tipo de programa encontra uma estética própria na estridência de suas locuções, como em certas passagens recuperadas para Rremembranças:

GG: Quem teria matado XXXXX? Aparentemente um local de diversão, de brinquedo. Mas agora é a Casa do Terror, e do terror mesmo. E, por enquanto, tudo é mistério. Quem teria matado XXXXX? O local de diversão, de brinquedos. $O$ medo virou medo de verdade. A morte da Menininha de Diadema...Gil Gomes, Aqui Agora. (XAVIER, 2006: 56)

O rodeio retórico e emocional nada informa, é pura gordura verbal. O contrário disso é a extrema economia das intervenções narrativas de Valêncio. Há uma precisão descritiva no uso que o autor faz das locuções que jamais se confunde com sua própria voz. Ao nos defrontarmos com seu quase-silêncio de narrador, nós nos confrontamos com o oco da retórica do telejornal.

Para comentar o detalhe tétrico de a menina ter sido encontrada no trem-fantasma do parque de diversões, Valêncio insere o único parágrafo de sua autoria, no sentido tradicional do termo, e o choque com os materiais reaproveitados é tamanho que ele chega a assinar o pequeno texto: "Trem-fantasma coisa nenhuma. O Mundo do Terror é um barracão bem vagabundinho, de tábuas desencontradas, coberto de lona e dentro dele não tem nenhum trem-fantasma. V.X.". Também o silêncio sintético dos números serve à sua escrita, cálculos-comentários como o "=7" que se refere à fala da mãe da vítima, "tenho sete fillhos

GIL GOMES NO PARGUE DE DIVERSD̃ES

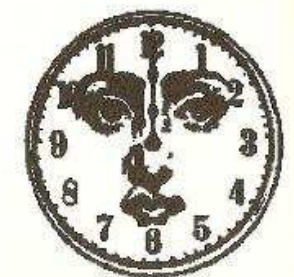

\footnotetext{
foi vista no parque, ao lado do parque, dentro do parque. Tambem depois ninguím mais a wiu. Teria-feira, guatro dias haviam se passado e nesse local, a denominada Casa do Terror, teve un mat cheiro musito grande.

Trem-fantasma coisa nenhuma. O Mundo do Terror é um barracão bem vagabundinho, de tábuas desencontradas, coberto de lona 0 dentro dele nåo tem nenhum trem-fantasma. $V . X$. GG: De onde vinha aquele mau cbeiro? De deniva da Casa do Terror Mas provinha do qué? Se procura pela Casa do Terror
}

Olveres procuron Osios. Humberto Pereira da Silva, de 35 , 0 Ne. as, tambem funcionario, e avison gre poderia ter um bicho morto no Trem-tantosma. Depojis de vistorias mimios atabos de ogra, esqueleo túmulos, eles abriram os caixó es de madeiras instalados numa das salas.

fora o que já morreu” (XAVIER, 2006: 47, 52).

E avançamos para que ao final de Rremembranças não saibamos o desfecho da história, enxergamos afinal em seu silêncio estranho algo como um correspondente estético deste desconhecimento. Não sabemos quem assassinou a criança, qual dos multiplicados suspeitos mentia, quais diziam a verdade, quem era culpado. A última matéria publicada pela imprensa sobre o caso ("Polícia suspeita de mais um em morte no parque", Folha de S. Paulo, 10/04/93) anuncia apenas a entrada de um personagem a mais na trama, de mais um suspeito. E avançamos para o escuro de uma página preta, e a última coisa que lemos 
do texto é a enigmática pergunta: "8 ou 9?".

Ocorre que no decorrer das páginas dos cadernos policiais e das locuções de TV, em meio à gritaria da imprensa, nenhum repórter se deu ao trabalho de confirmar a idade da menina morta, que nos recortes varia entre oito e nove anos, a depender da fonte. Não há explicação para a morte como não há precisão de fatos, e a narrativa de V.X. nada resolve, só duplica nosso desconforto oferecendo a um caso com desfecho trágico uma história com final aberto.

\section{Bibliografia:}

BUCCI, Eugênio. Da pancadaria explícita à violência invisível. In: O peixe morre pela boca: oito artigos sobre cultura e poder. São Paulo: Scritta, 1993. p. 93 - 129.

DEBORD, Guy. A negação e o consumo na cultura. In: A sociedade do espetáculo. Rio de Janeiro: Contraponto, 1997. p. $119-137$.

JAPPE, Anselm. A Internacional Letrista. In: Guy Debord. Lisboa: Antígona, 2008. p. 65 - 84.

LOTMAN, Iúri. Acerca de la semiosfera. In: La Semiosfera I: Semiótica de la cultura y del texto. Trad. Desiderio Navarro. Madrid: Ediciones Cátedra, 1996. p. 21 - 42.

. La memoria a la luz de la culturología. In: La Semiosfera I: Semiótica de la cultura y del texto. Trad. Desiderio Navarro. Madrid: Ediciones Cátedra, 1996. p. 157 - 162.

. The notion of boundary. In: The Universe of The Mind: a semiotic theory of culture. Trad. Ann Shukman. Indiana University Press, 1999. p. 131 - 144.

TERRON, Joca Reiners. O grande circo freak de Valêncio Xavier. In: XAVIER, Valêncio. Meu $7^{\circ}$ Dia. São Paulo: Ciência do Acidente, 1999. p. 48 - 55.

WILlER, Claudio. Prefácio: O Astro Negro. In: Lautréamont. Os Cantos de Maldoror. São Paulo: Iluminuras, 2008. p. $13-69$.

XAVIER, Valêncio. Crimes à moda antiga - Contos Verdade. São Paulo: Publifolha, 2004.

. Meu $7^{\circ}$ Dia. São Paulo: Ciência do Acidente, 1999.

. O mez da grippe e outros livros. São Paulo: Companhia das Letras, 1998.

Rremembranças da menina de rua morta nua e outros livros. São Paulo: Companhia das Letras, 2006.

\section{Notas:}

(1)Tendo estreado na literatura em 1964, Valêncio só reúne seus muitos textos em livro em 1998, quando passa a ser editado pela Companhia das Letras. As datas de publicação utilizadas neste estudo obedecem as das publicações em livro. 
(2)Cite-se como ilustração os dois ready-mades do artista francês baseados na Mona Lisa, de Leonardo da Vinci. Em 1919, Duchamp exibe uma reprodução do famoso quadro com o acréscimo de um bigode desenhado a lápis e da inscrição Elle a chaud au cul, algo como "ela tem fogo no rabo". Décadas mais tarde, exibe uma reprodução do mesmo quadro, mas sem o bigode, ou seja: a própria Mona Lisa. Há de acréscimo apenas a assinatura de Duchamp, e uma legenda com o título da obra: "Barbeada".

(3)“La no homogeneidad estructural del espacio semiótico forma reservas de procesos dinámicos y es uno de los mecanismos de producción de nueva información dentro de la esfera. En los sectores periféricos, organizados de manera menos rígida y poseedores de construcciones flexibles, 'deslizantes', los procesos dinámicos encuentran menos resistencia y, por consiguiente, se desarrollam más rapidamente".

(4)Sobre a utilização de técnicas de reaproveitamento de materiais ao longo da história da cultura, vem ao caso a lembrança de um parágrafo do sociólogo e filósofo alemão Anselm Jappe, retirado de um estudo sobre Guy Debord, os situacionistas e suas conexões com outros movimentos político-culturais da modernidade, como Dada, surrealismo e letrismo. "Os letristas, em vez de criarem formas inteiramente novas, preferem retomar elementos já existentes para os dispor de modo distinto. Esta técnica do 'reaproveitamento' que remonta, por um lado, à 'colagem' dadaísta e, por outro, às citações deformadas adoptadas por Marx e Lautréamont, denomina-se détournement - palavra que, habitualmente, pode ser traduzida por 'desvio', mas também significa 'subtracção' (ou 'sequestro', 'apropriação') e 'distanciamento' (há ainda quem fale, em português, de 'diversão' e 'subversão'). Trata-se de uma citação, ou de uma reutilização num sentido mais geral, que 'adapta' o original a um novo contexto. É também uma maneira de superar o culto burguês da originalidade e da propriedade privada do pensamento. (...) O détournement baseia-se numa dialéctica de desvalorização e revalorização". (JAPPE, 2008: 80)

\section{Mini Currículo :}

Reuben da Cunha Rocha (Mestrando em Ciências da Comunicação pela ECA-USP. reubencr@gmail.com) 